\title{
The Trencadis Mosaic on the Pinnacles of the Sagrada Familia Cathedral
}

\author{
Júlia Gómez-Ramió, Sergio Cavalaro, and Antonio Aguado \\ Universitat Politècnica de Catalunya, Department of Construction Engineering, Barcelona, Spain
}

The architect Antoni Gaudí developed a unique constructive solution for the pinnacles that crown his last work, the Sagrada Familia. It consisted of fashioning the finishing components from precast pieces of lightly reinforced concrete that was covered with a trencadis mosaic of Murano glass. With this solution, Gaudí invented a singular coating material that responded to the special ambient conditions of a construction at great height, keeping esthetic and decorative aspects in mind. Those who have continued his work up to this day still employ this constructive system to complete the new pinnacles and in the decoration of other parts of the cathedral. The main objective of this study is to explain the conception and the constructive logic of the Sagrada Familia pinnacles, as well as its evolution since the beginning of the 20th century. For that focus, a review of the way in which Gaudí applied the trencadis coating in his earlier works is presented. Likewise, the reasons that

20 led the architect to select a unique glass imported from Italy for the trencadis on the temple pinnacles are revealed.

Keywords Sagrada Familia, trencadis, pinnacles, Murano glass, coating

\section{INTRODUCTION}

The architect Antoni Gaudí understood architecture as a complete universe and poured all his creativity and rationality into even the smallest details. The pinnacles of the Sagrada Familia are a good example of that. The architect designed a unique constructive solution in these elegant spires that responded to the special ambient conditions of a construction at great height, keeping esthetic and decorative aspects in mind.

The pinnacles of the Sagrada Familia were constructed with lightly reinforced precast concrete covered in the same manufacturing process with a trencadis of opaque glass, especially imported from the Murano Islands (Venice). Gaudí had applied the exterior trencadis coating in many of his works with a great variety of materials and techniques, turning it into one

Received May 22, 2013; accepted August 8, 2013.

Address correspondence to Júlia Gómez-Ramió, Department of Construction Engineering, Universitat Politècnica de Catalunya, Edifici C1, Campus Nord UPC, Jordi Girona 1-3, 08034 Barcelona, Spain. E-mail: julia.gomez@upc.edu of his most distinctive hallmarks. However, none of these had achieved such heights as the Sagrada Familia. The definition of its finishing touches was a challenge for the architect. This led to a solution unseen in his previous work. A solution in which he applied much of his constructive, geometric, and material experience gained throughout his professional career.

Inaugurated on November 30, 1925, the tower of the Nativity facade that rises up almost 100 meters to its peak is dedicated to Saint Barnabas (Figure 1a). This pinnacle was the first and only of the Sagrada Familia project that Gaudí would see to completion. Since his death up until the present day, this unique construction system using precast elements with a trencadis coating of Murano glass is still applied for the construction of new pinnacles (Figure 1b) and decoration of other parts of the Cathedral.

Given the uniqueness of these elements and their constructive system, the main objective of this paper is to explain the conception and the constructive rationale of the Sagrada Familia pinnacles, as well as its evolution over time. To do so, a review the way in which Gaudí applied the trencadis coating in this earlier works is presented. Likewise, the reasons that led the architect to select a unique glass imported from Italy for the trencadis facing on the temple pinnacles are revealed.

Once the design motifs that Gaudí applied to the pinnacles are discussed, the evolution of their on-site construction from the first pinnacle of Saint Barnabas until the most recent works of the Japanese sculptor, Etsuro Sotoo is analyzed. This analysis is done by dividing the work of the Sagrada Familia into three historical stages. The earliest of them (1915-1930) covers the life of Gaudí and the construction of the Nativity facade pinnacles. The second (1952-1978) includes the construction of the pinnacles of the Passion facade by the direct disciples of Gaudí. Finally, the most recent covers the period up until the present day (1985-2012).

\section{TRENCADIS IN GAUDÍ'S WORK: THE COATING AND PRECAST ELEMENTS}

In his student days, Antoni Gaudí felt an attraction for oriental architecture while looking through collections of books and photographs in the library of the Escuela de Arquitectura de 


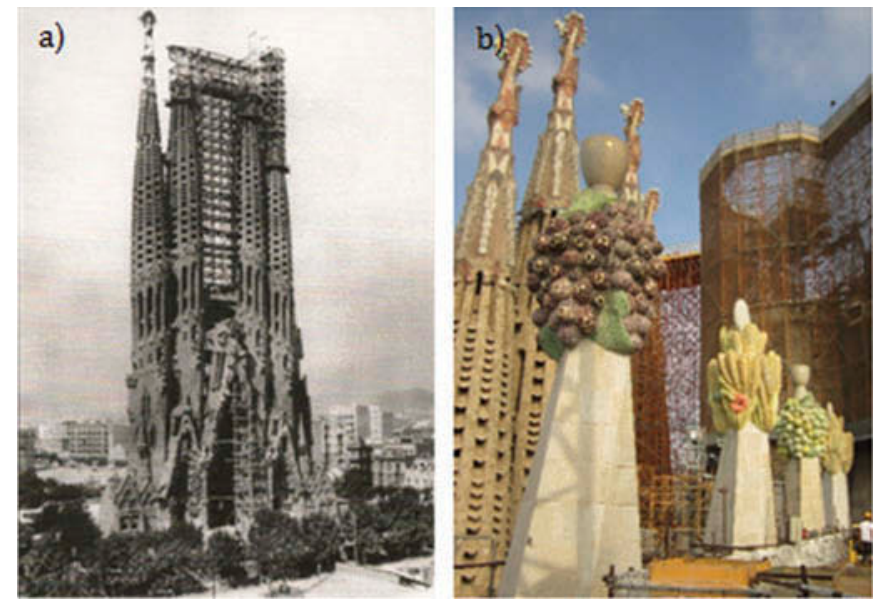

FIG. 1. (a) Nativity façade in 1926 and (b) new pinnacles of Sagrada Familia in 2012. (C) J. Bonet. Reproduced by permission of J. Bonet. Permission to reuse must be obtained from the rightsholder.

Barcelona, the Architectural School of Barcelona (Bergós and Llimargas 1999; Martinell 1967). Very probably influenced by these styles, he had dedicated special attention to exterior decorative ceramics ever since his first works. Examples may be found in his earliest works such as the Casa Vicens (1883-1888) (Figure 2a) or the Capricho (1883-1885), where he covered the building facades with rectangular patterns of polychrome enameled ceramics.

In 1884, the young architect designed an innovative coating for the dome of the Picador and the chimneys of the porter's lodge at the Finca Güell (Bassegoda Nonell et al. 1984) as shown in Figure $2 \mathrm{~b}$. The technique, popularly known as trencadis, consisted of breaking the enameled ceramic pieces into small polygonal fragments that were applied in a unique
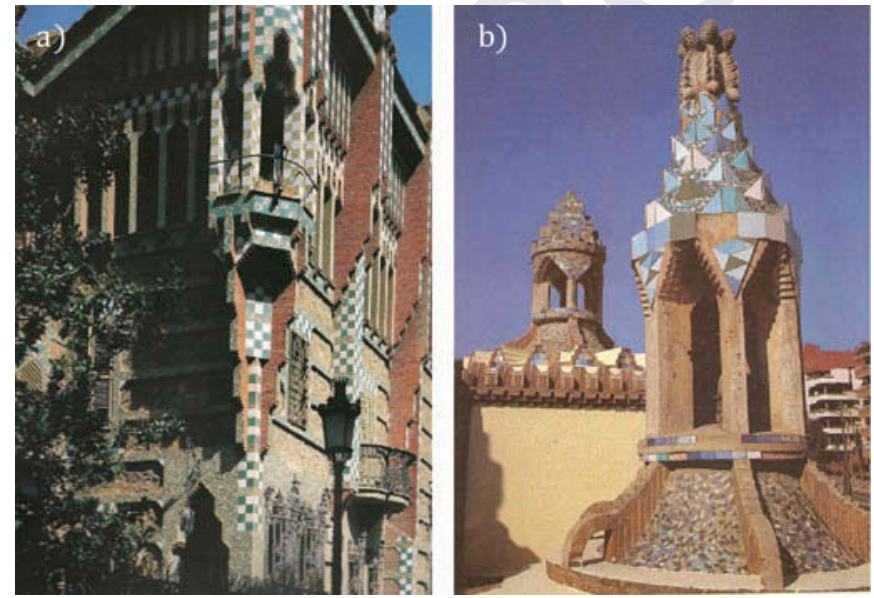

FIG. 2. (a) Facade of the Casa Vicens and (b) chimneys of the porter's lodge at the Finca Güell. () (a) J. Bergós and (b) J. Bassegoda Nonell. Reproduced by permission of ( $\odot$ (a) J. Bergós and (b) J. Bassegoda Nonell. Permission to reuse must be obtained from the rightsholder. mosaic of different tonalities over a lime mortar base. This technique permitted the adaptation of rectangular pieces available on the market to the ruled surfaces of his works and the use of practically all the pieces since they were broken. Given his interest in geometry and oriental culture, some authors have established a link between his designs and the centuries-old ceramic work of zellige or zillij mosaics (Bassegoda Nonell et al. 1984).

Later on, the architect returned to this technique in the Palau Güell (1886-1890), for the coating on the chimney and lantern-dome that decorates the roof of the palace. In these structures, Gaudí also began experimenting with the trencadis technique, using other materials such as marble, glass, stone (Figure 3a) and refractory bricks from the inner lining of lime ovens (González Moreno-Navarro 1993).

The successive works of the architect, such as the Palacio Episcopal de Astorga (1883-1893), Casa de los Botines (1885-1892) or the Colegio de los Teresianas (1888-1890) are characterized by their eclecticism, with a particularly discrete use of decorative ceramics. However, Gaudí once again employed a "mosaic stone", similar to the roof of the Palau Güell mentioned above, at the beginning of the 20th century, such as the Parque Güell (1900-1905) and the Casa Bellesguard (1900-1909). In these cases, Gaudi took the technique a step further, developing a constructive system of precast elements with this material. Such technique was applied between 1901 and 1903 in the construction of various elements for the viaducts and retaining walls of Parque Güell (Paricio 1981), as shown in Figure 3b.

The success obtained led to the implementation of a construction site at Bellesguard (1900-1909) where various facade elements were prepared such as lintels, jambs and different
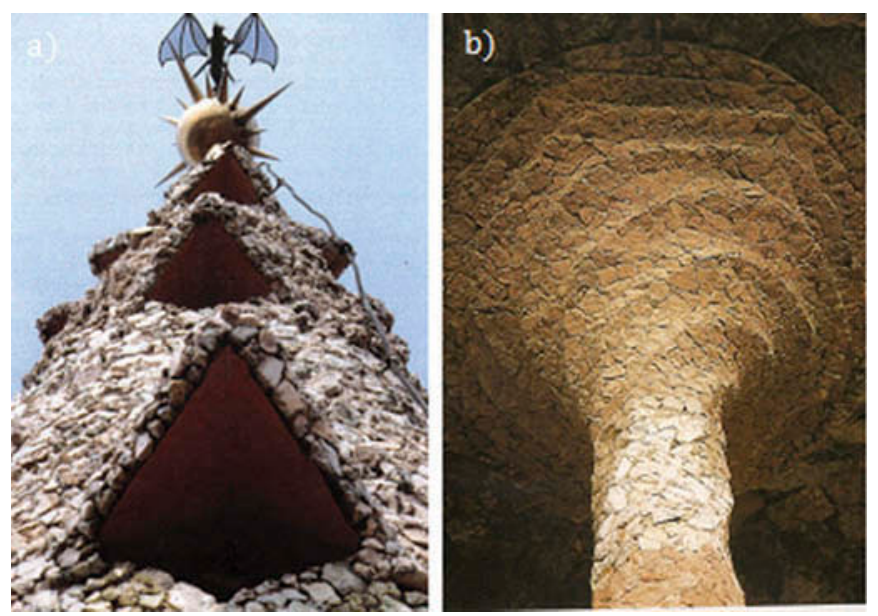

FIG. 3. (a) Dome-lantern of Palau Güell and (b) precast colonnade supporting a retaining wall over a walkway in Parque Güell. () (a) A. González MorenoNavarro and (b) J. Bergós. Reproduced by permission of (a) A. González Moreno-Navarro and (b) J. Bergós. Permission to reuse must be obtained from the rightsholder. 
types of finishes. According to the literature, the precast pieces at Bellesguard were fabricated on site. First of all, a plaster mold in the desired form was made from a clay model. Subsequently, the workers placed stones from the local area at the bottom of the mold and filled it with a quick-drying cement mortar. Once hardened, the piece was turned out of its mold and left to dry until it's positioning on the facade (Bassegoda Nonell 1989).

The trencadis appeared another time in the construction phase of the entrance to Parque Güell (1903-1905). To do so, two constructive systems were used. First, direct application of the coating was employed for large areas, such as the entrance halls (Figure 4a). Second, the architect used precast elements for the construction of small-scale, repetitive figures, such as finishing elements on the entrance wall and coatings on the lateral walls of the main staircase (Figure $4 \mathrm{~b}$ ). According to the literature, unlike the on-site work at Bellesguard, these precast elements were cast in wooden molds and by positioning three courses of thin brick over the enameled ceramic trencadis that, with the addition of mortar, assumed the form of the mold. The first course was covered with a layer of quick-drying cement mortar and the following two with lime mortar.

Subsequently, in the rehabilitation work on Casa Batlló (1904-1906), Gaudí once again used the colors of enameled ceramic and glass on the exterior coating of his work. In this case, it appeared on a large part of the exterior envelope (facade, roof, and rooftop) and on the shared interior elements (hall and ventilation courtyard).

In all the decorative geniality of the work, the new trencadis coating placed on the existing facade must be highlighted. In this application, the architect decided to scrape away all the exterior masonry on the original surface to form wavy undulations. Then, he designed a fabulous trencadis coating placed on a new layer of lime mortar, with small pieces of colored glass and painted ceramic plates (Figure 5a). Notably, according to the former contractor of the work, Gaudí personally directed the decorative design of this facade. The architect stood in the middle of the Paseo de Gracia and indicated to each of the workers
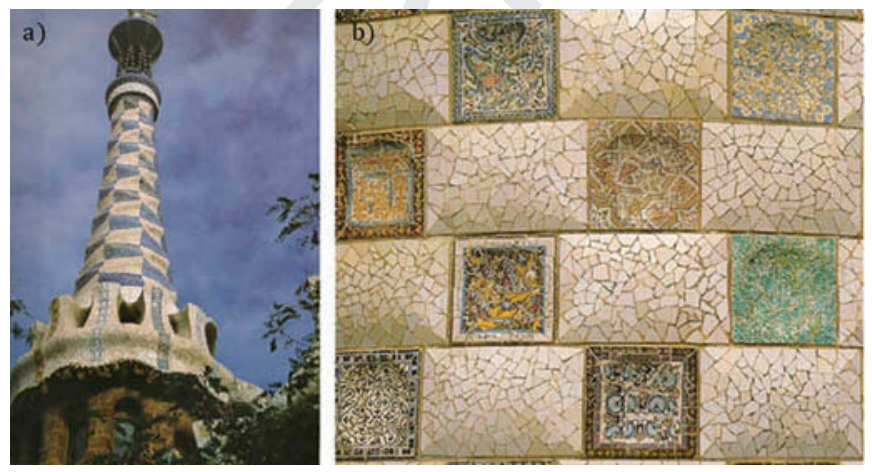

FIG. 4. (a) Roof the Parque Güell entrance hall, and (b) precast elements of the side walls of the main stairway. (C) (a) J. Bergós. Reproduced by permission of (a) J. Bergós. Permission to reuse must be obtained from the rightsholder.
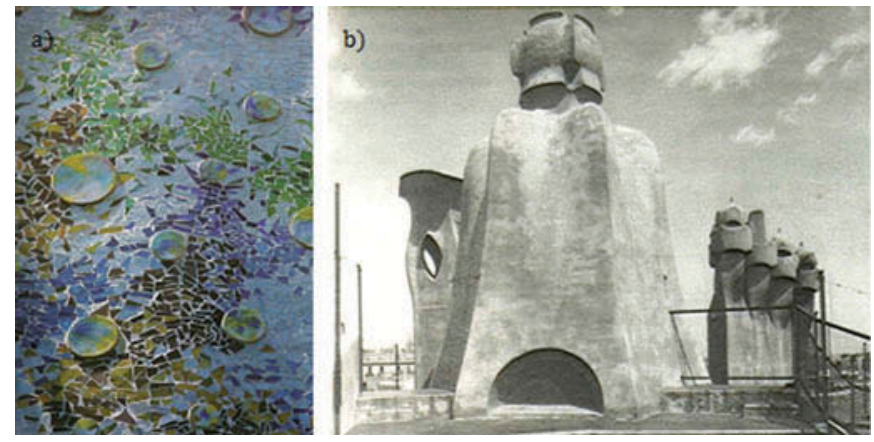

FIG. 5. (a) Detail of the Casa Batlló trencadis facingand (b) roof terrace under construction of the Casa Milà. (C) (a) J. Bergós and (b) J. Bassegoda Nonell. Reproduced by permission of (a) J. Bergós and (b) J. Bassegoda Nonell. Permission to reuse must be obtained from the rightsholder.

the exact position where the different tonalities of glass would be placed (Bassegoda Nonell 1989).

Some years later, in another work on Paseo de Gracia popularly known as La Pedrera (1906-1910), the architect returned to the trencadis technique used in the Palau Güell. However, in this case, he exclusively used white marble to cover the elements. As shown in Figure 5b, a layer of lime mortar was spread over the surfaces and thereafter, once the surface was dry, the marble trencadis was adhered to it with a second layer of mortar.

At the same time of this construction, progress continued on other parts of the Parque Güell, such as the Hypostyle Hall (1907-1909) shown in Figure 6a, and its upper square (1907-1914). However, following the completion of these parts, a lack of financing paralyzed Gaudí's idyllic project. Under these circumstances, the optimization of resources in the last part of the work was very important. For this reason, the precast pieces were key elements in its construction. In fact, some authors have referred to its construction as a structural meccano (Paricio 1981).

The precast pieces from this last part of the Parque Güell presented the same characteristics of the ones used in the entrance. However, for the first timer, they were conceived to have a significant structural responsibility, besides attending aesthetic aspects. As may be observed in the scheme of Figure 6b, the ceramic beams rest on the pillars of the hall forming a $4 \times 4 \mathrm{~m}$ grid. Above them, ceramic calottes in the form of small vaults are covered with ceramic tiles. Aware of the bending stresses that those beams had to resist, Gaudí placed two rectangular strips of metal in the form of coils embedded in a layer of mortar in its lower section as passive reinforcements (Figure 6b, Sections A-A' and C-C'). These reinforcements were then filled by several courses of ceramic tiles (Martinell 1967).

It is noteworthy that the same coiled metallic strips also appear in the structural beams of the park entrance halls. In the most recent investigations into Gaudí's knowledge of reinforced concrete, a link has been established between these coiled metal strips and a patent registered in Barcelona during the same period by Habrich (Grima et al. 2007). 

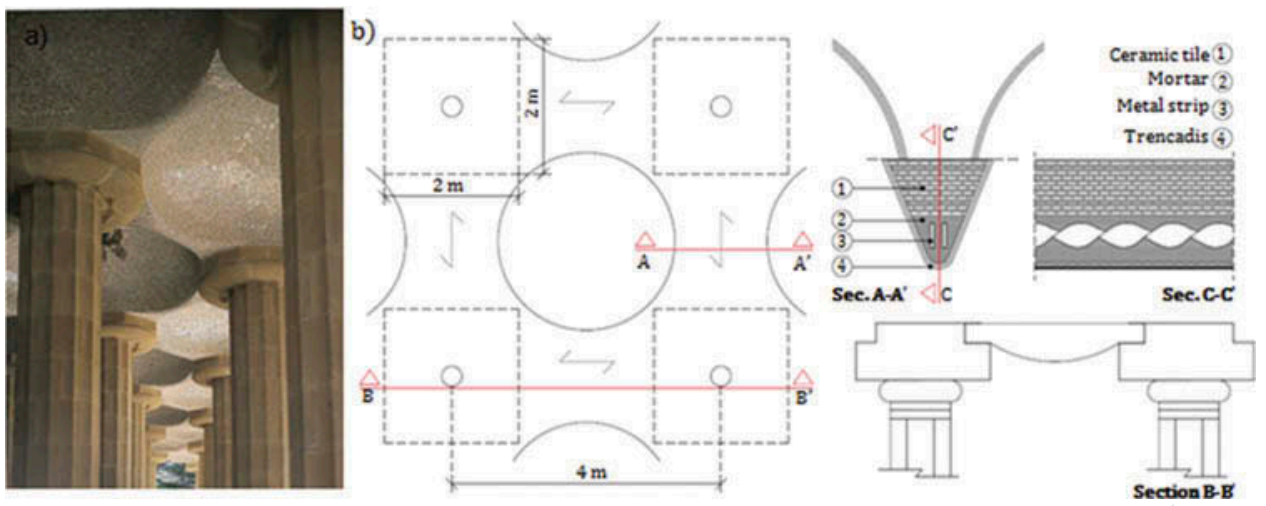

FIG. 6. (a) Interior of the Hypostyle Hall and (b) structural scheme of slabs in the Hypostyle Hall. () (a) J. Bergós and (b) A. Mañà. Reproduced by permission of (a) J. Bergós and (b) F. Mañà. Permission to reuse must be obtained from the rightsholder.
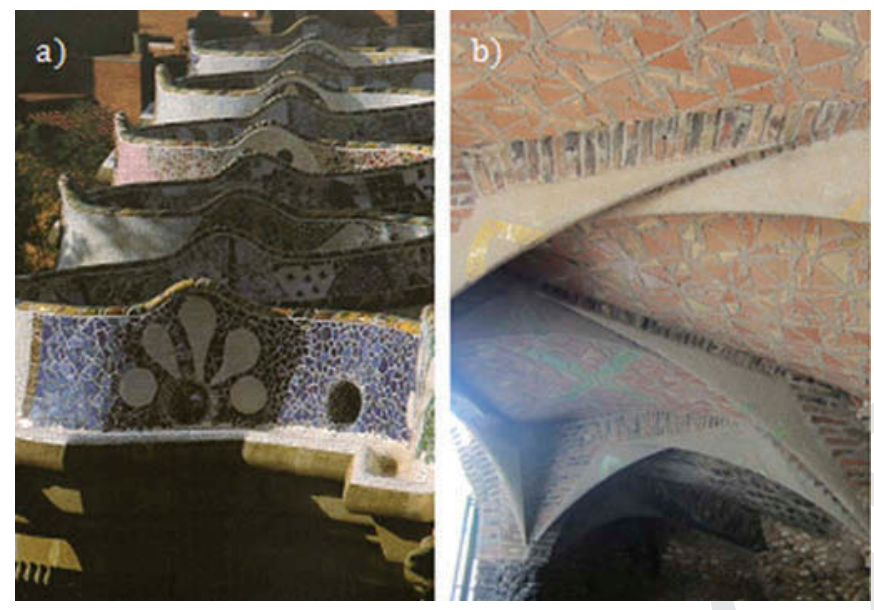

FIG. 7. (a) Parapet at the edge of the upper square of Parque Güell and (b) roof of the entrance porch leading into the crypt of the Colonia Güell (2011). (C) (a) J. Bergós. Reproduced by permission of J. Bergós. Permission to reuse must be obtained from the rightsholder.

Moreover, precast elements were also used in the construction of the park and covered with trencadis when placed on site. An example of this may be found in the parapet winding along the perimeter of the upper square completed between 1910-1913 (Figure 7a). In this case, direct application of the trencadis is attributed to the need to conceal the joints between the symmetrical pieces that form the parapet.

Subsequently, the architect returned to the trencadis technique for the external decoration of the windows and for the coating of the roof of the entrance porch, as seen in Figure $7 \mathrm{~b}$. In these parts, the trencadis did not follow a random composition nor was it grouped by color as in his previous works. Instead, the architect broke the rectangular ceramic pieces into four triangles, which were then placed in the same direction as the two sets of generating lines that defined the hyperbolic paraboloid roof (González Moreno-Navarro et al. 2002).
Gaudí abandoned the construction in Colonia Güell and retired in the last few years of his life to the temple of the Sagrada Familia to develop the project that had accompanied him throughout his professional career. In the Cathedral, the works continued at a good pace thanks to generous donations (Bonet et al. 2010). Despite that continued work, in 1905, the pace slowed down as funds started to dry up and donations dwindled being even paralyzed at some point. In this period, the architect spent his time defining many remaining parts of the project (Martinell 1967). Among these, Gaudí developed the definitive solution for the pinnacles, in which he used the characteristic trencadis coating on the Sagrada Familia for the first time.

\section{THE DESIGN OF THE PINNACLES}

Gaudí experimented with many small-scale models of different parts of the Cathedral in order to define the complex forms of the project. An important part of the creative process was done in the study that the architect kept next to the site of the temple, also known by the name of Obrador (GómezSerrano 1996) One of the first versions of the Nativity facade in model form was presented, in 1910, in Paris, in front of the Societé Nationale des Beaux-Arts (Figure 8a), in an exhibition sponsored by his friend and sponsor Eusebi Güell (Bonet et al. 2010).

According to his disciple, Juan Matamala (1999), in this preliminary version of the future facade, each tower was completed with a gilded bronze structure and with a hexagonal viewing balcony flanked by two sculpted angels. Their wings would ensure the safety of future visitors who might wish to visit it.

The final version of the pinnacles that today tops the Nativity facade was developed around 1915 at the same time the architect presented the second version of the transversal section of the temple (González Moreno-Navarro et al. 2002). Their unique shapes quite distant from the first version presented at the Paris exhibition, represented the episcopal miter and crosier. 

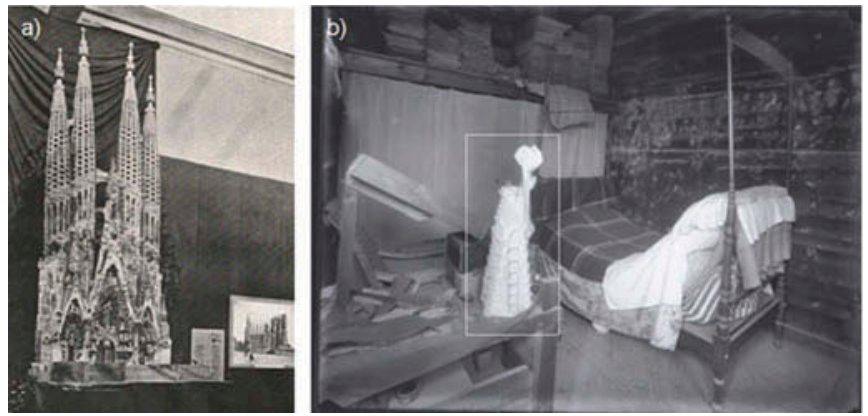

FIG. 8. (a) Model of the nativity facade presented in Paris in 1910 and (b) photograph of Gaudî's Obrador study. (C) (a) Archivo Histórico De La Basílica De La Sagrada Familia. Reproduced by permission of Archivo Histórico De La Basílica De La Sagrada Familia. Permission to reuse must be obtained from the rightsholder.

250 Gaudí also worked with a small-scale plaster model for its definition. This approach was observed in one of the photos of the Obrador study published in the Gaseta de les Art journal shortly after his death in 1926, shown in Figure 8b (Gómez-Serrano 1996).

255 The decorative solution of the temple pinnacles was defined as a trencadis coating, just like in many of his previous works. The architect experimented with a great variety of materials in the application of this type of coating: enameled ceramic in the chimneys of Palau Güell, glass on the facade of Casa Batlló and marble in the chimneys of the la Pedrera or Casa Milà. Aware of the deterioration of these materials, of the severe conditions found on site and of the difficulty to access and repair the pinnacles (Bassegoda Nonell et al. 2006), the architect decided to experiment with more resistant materials that would maintain its performance when applied at height.

Juan Matamala (1999) suggested that Gaudí hung on the walls of his studio various photos of glass tiles mosaic works taken from his archive of graphic documents, while working on the temple decoration project. The glass tiles mosaic is composed of small pieces of gilded and opaque polychrome glass placed over a lime mortar base. This unique coating, that allows high adaptability to complex constructive forms, was used, during the centuries, to cover both flat or curve surfaces. Different examples are preserved, dating at the earliest from the late antique or early Middle Ages (among others, the Saint Marks Basilica in Venice, San Vitale in Ravenna, San Clemente in Rome, in Sicily the Monreale Dome or the Palatine Chapel in Palermo, or Santa Sofia in Constantinople).

In the present work, after a thorough investigation of the photos of Gaudi's studio published on 1926 (Figure 9), several images were observed on the walls. According to the literature, these images or perhaps postcards were brought home by his friend and colleague Lluís Bonet after a trip to Italy (Gómez-Serrano 1996).

The real sites corresponding to some of the images were identified in the present study. Table 1 provides a zoomed view

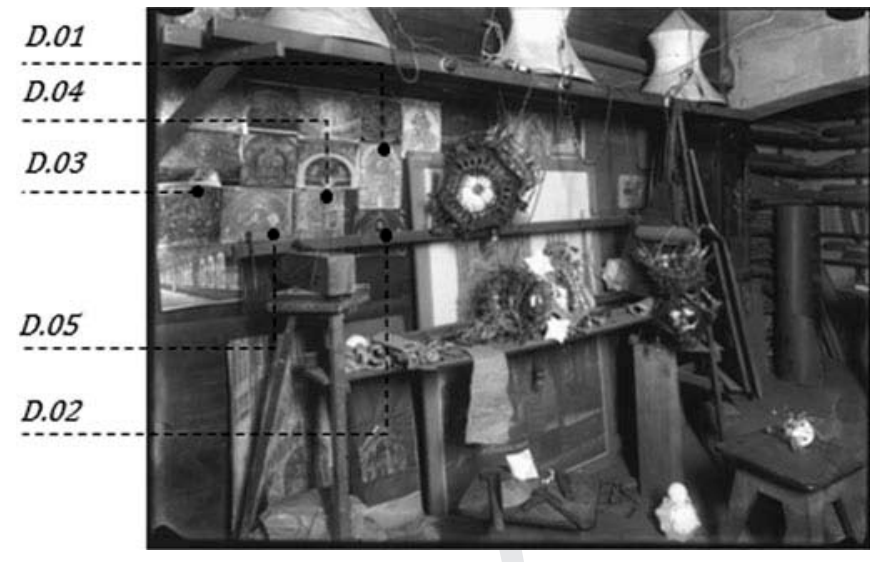

FIG. 9. Wall with the photographs of glass tiles mosaics works from Gaudi's studio. (c) (a) Archivo Histórico De La Basílica De La Sagrada Familia. Reproduced by permission of Archivo Histórico De La Basílica De La Sagrada Familia. Permission to reuse must be obtained from the rightsholder.

of the images from Figure 9 and the recent photos with the real site names. It is clear that the constructions identified in Gaudi's study belong to different interior coatings of historical buildings on the island of Sicily, such as the Duomo di Monreale, the Palatine Chapel, and the Duomo di Cefalù. All of them were the basis for the definition of the coating of the pinnacles.

In 1916, having commenced the construction of the base of the pinnacles, Gaudí sent his disciples Rafols and Bonet to the Murano islands of Venice. The purpose of their trip was to report on the properties and characteristics of this unique glass that he had studied, so that it could be used on the pinnacles of the towers (Bassegoda Nonell 1996) .

\section{CONSTRUCTIVE EVOLUTION OF THE SAGRADA FAMILIA PINNACLES}

\subsection{First Stage (1915-1930): Nativity Facade}

The first completed tower of the Nativity facade was the one dedicated to Saint Barnabas (Figure 1a). This tower with a pinnacle that rises up to a height of 100 meters was inaugurated on November 30, 1925. In total, 4 long years were required for the construction of the pinnacle due to the difficulties to obtain the glass that was imported from the locality of Murano (Matamala Flotats 1999) at a high price and a slow supply rate. According to a disciple of the architect, a bishop who learnt of the lengthy delays of the glass for the mosaics suggested that Gaudí order glass from Valencia, as it would probably be supplied more quickly. The architect replied that it was not a question of faith and that he preferred to wait for the Venetian tessella, even though its delivery would slow down his construction work (Martinell 1967).

The Saint Barnabas pinnacle with $24.60 \mathrm{~m}$ of height is composed of two clearly differentiated parts (Figure 10). The base of the pinnacle accounted for the first $7.60 \mathrm{~m}$ and was 


\section{TABLE 1}

Comparison of the photographs from Gaudí’s study (Velmans et al. 1999). (C Archivo Histórico De La Basílica

De La Sagrada Familia and T. Velmans. Reproduced by permission of Archivo Histórico

De La Basílica De La Sagrada Familia and T. Velmans. Permission to reuse must be obtained from the rightsholder

\begin{tabular}{|c|c|c|c|}
\hline Description & & $\begin{array}{l}\text { Zoom image from } \\
\text { Gaudi's study }\end{array}$ & Recent photo \\
\hline D.01 & $\begin{array}{l}\text { Absidal Mosaic Monreale di Duomo } \\
\text { Monreale, Sicily }\end{array}$ & & \\
\hline D.02 & $\begin{array}{l}\text { Absidal Mosaic Monreale di Duomo } \\
\text { Monreale, Sicily }\end{array}$ & & \\
\hline D.03 & $\begin{array}{l}\text { Mosaic dome of the Palatine Chapel. } \\
\text { Palermo, Sicily }\end{array}$ & & \\
\hline D.04 & $\begin{array}{l}\text { Mosaic facing of the central apse of } \\
\text { the Palatine Chapel. Palermo, } \\
\text { Sicily }\end{array}$ & & \\
\hline D.05 & $\begin{array}{l}\text { Apsidal mosaic of the Duomo di } \\
\text { Cefalù.Cefalù }\end{array}$ & & \\
\hline
\end{tabular}

constituted by a concrete core poured in situ between two faces of formwork.

The internal surface of the permanent formwork served at the same time as facing final coating. This was executed with pieces of granite, with the inscription Hosanna and Exceleis, in white glass. These pieces were simultaneously positioned at intervals between masonry work showing ears of wheat. The hoists with the stone blocks moving up to the wooden scaffolding around the tower may be seen in Figure 11a. Moreover, wooden formwork was also used for the inner coating. This may be observed through a visual inspection on the inside of the pinnacle, where the imprint of the formwork is clearly visualized (Espel et al. 2009).
The second part and crown of the pinnacle extends for the last $17 \mathrm{~m}$ and represents the episcopal mitre and crosier. This part was constructed with precast concrete lightly reinforced with steel mesh and covered with a trencadis of Murano glass. According to an interview with an old construction worker present during the construction of the Passion facade, these pieces were cast on site, following Gaudí's instructions. First the small glass fragments were placed at the bottom of a mold, forming the trencadis facing and then the mold was filled with concrete (Grima 2004). This manufacturing system achieved smooth surfaces for the complex geometries of the architect and facilitated its positioning on site (Figure 11b). 

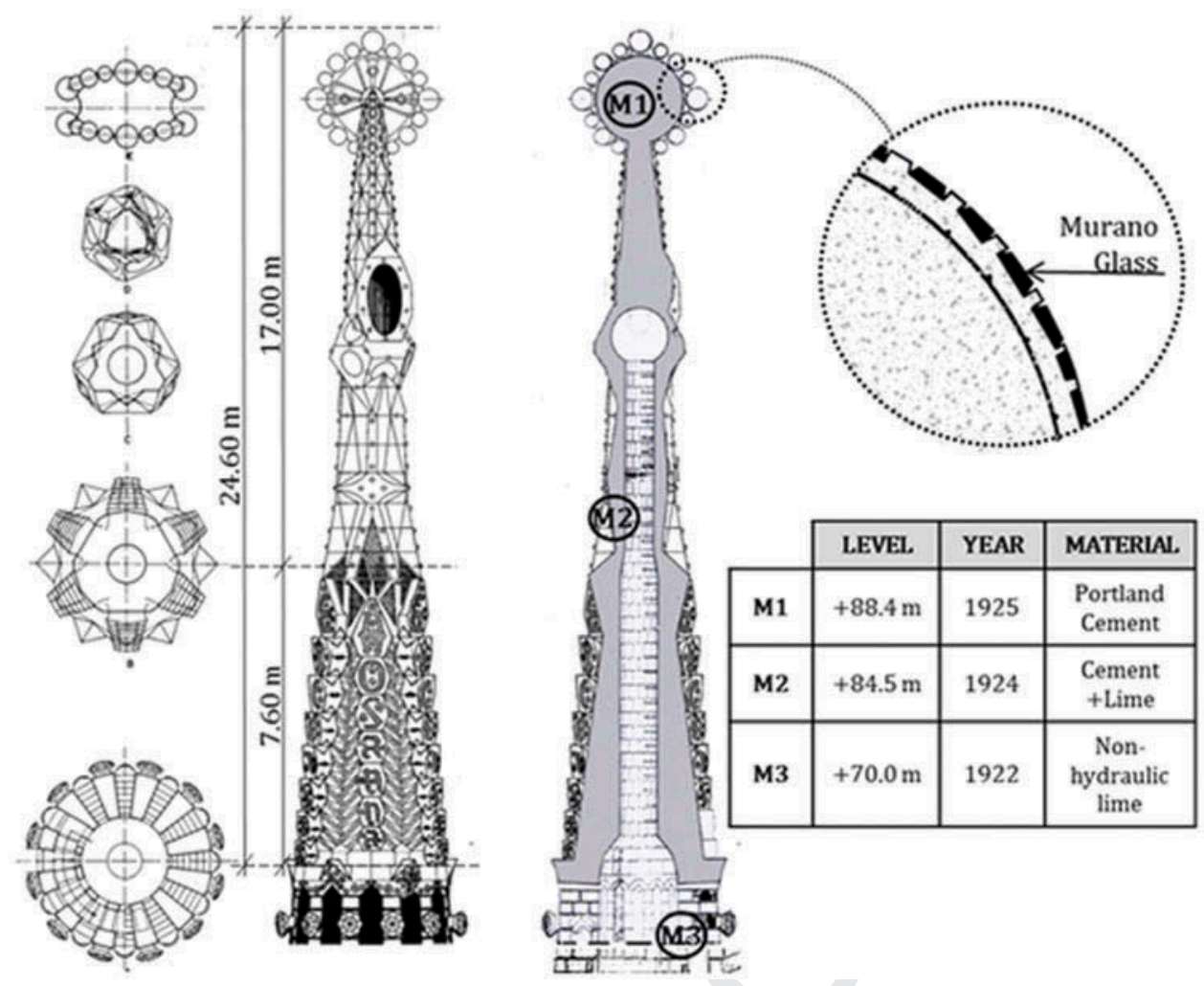

FIG. 10. Plant view, side elevation and cross-section of St. Barnabas pinnacle.
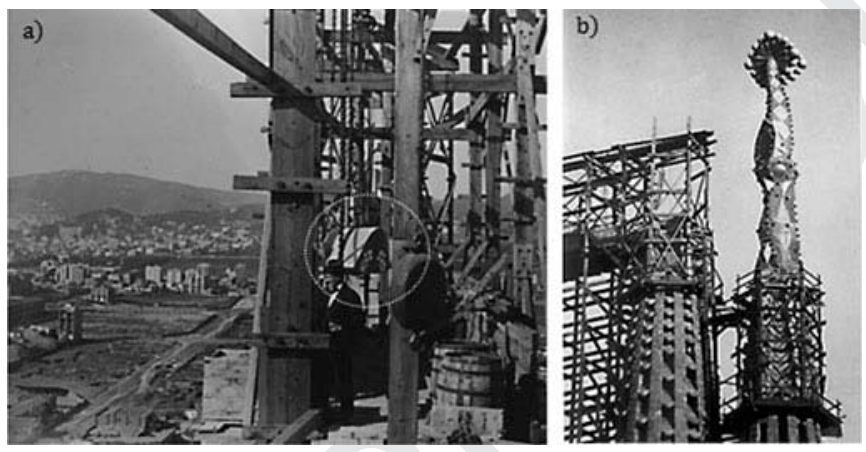

FIG. 11. (a) Hoisting of the pieces of the base pinnacle and (b) wooden scaffolding for the construction of the pinnacle. (c) (a) Archivo Histórico De La Basílica De La Sagrada Familia. Reproduced by permission of Archivo Histórico De La Basílica De La Sagrada Familia. Permission to reuse must be obtained from the rightsholder.

In 1997, three samples extracted from the St. Barnabas pinnacle were chemically characterized by Lend Chemical Analysis Consulting and the Department of Crystallography and Mineralogy of the Geology Department of Barcelona University (Carbonell De Massy 1997). These samples may be seen under the labels M1, M2 and M3 in Figure 10. Based on the results, the presence of unhydrated clinker could be determined in two of the samples taken from the top of the pinnacle (M1 and M2).
A small quantity of gypsum was also found in one of these samples (M2). According to the aforementioned report, this was due to the use of white Portland cement (Carbonell De Massy 1997). However, recent research shows that the company Asland, owned by Gaudi's sponsor Eusebi Güell and the supplier of Portland cement to the construction, was not manufacturing white cement in that period. Based on the above, a hypothesis were formulated to explain the presence of gypsum in the mortar: it may have been used as the concrete set retarder, a common practice at the time (Grima 2004).

The presence of calcite was also found in the same analyses of samples containing Portland. According to the report, the small amount found in the sample M1 extracted from the highest point, may be attributed to the aggregate composition of the mixture. However, the larger presence in sample (M2) suggested the incorporation of lime in the mixture. The use of lime was well known by Gaudí and it is easy to imagine that the architect incorporated lime to increase the flexibility of the base given the stresses that the base of the pinnacles would have to resist (Grima 2004).

As previously mentioned, Gaudí only lived to see the completion of the Saint Barnabas tower. Following his accidental death on June 11, 1926, his disciple Doménec Sugranyes (1927-1936) continued working on the Nativity facade, until its completion in 1930 (Bassegoda Nonell 1989). 
380

\subsection{Second Stage: The Successors of Gaudí (1952-1978)}

Precast pieces with a trencadis covering of Murano glass were not used again until construction of the pinnacles of the Passion Facade, between 1952 and 1978 (Bassegoda Nonell et al. 2002). After the death of Doménec Sugranyes in 1938, the management of the construction work at the temple was handed over to Francesc Quintana (1892-1966), another disciple of Gaudí. At that time, the construction presented devastating damage due to arson attacks in the Spanish Civil War from 1936 to 1939 (Bonet et al. 2010). However, thanks to a generous donation received before the start of the war, Quintana and his team began a cleaning work, the restoration of the crypt, and the recovery of some of Gaudí's models (Bonet et al. 2010) .

In this period, Francesc Quintana coordinated a management team with the other closer disciples of Gaudí, who successively assumed leadership: Isidre Puig Boada between 1966-1974, and Lluís Bonet and Garí between 1971-1983 (Espel et al. 209). The commencement of the Passion facade started with a drawing by Gaudí in 1911. The architect in his lifetime had told his disciples that it would be enough with this design to continue the project (Bonet et al. 2010).

The Sagrada Familia project is composed of three facades that represent the three important moments in the life of Jesus Christ (birth, death and resurrection). Each one corresponds to one of the main entrances to the Basilica: the Nativity and the Passion facades, are situated at the two ends of the transept and the Gloria Facade is the direct access to the main building. Geometrical relationships are established between them as in the rest of the project. According to a direct disciple of Gaudí, when the bell towers of the Passion facade leave the square section and assume elliptical forms, the small diameter of the latter figure corresponds to the diameter of the towers of the Nativity facade and the large diameter is the same as those of the circles of the Gloria façade (Puig Boada 1929).

The main material used throughout construction of the Passion facade was concrete. The decision to use this material was most probably based on three factors. First, Gaudí had introduced this material for the Saint Barnabas pinnacle. Second, concrete in that postwar period was a cheaper material than stone and third, technical knowledge of concrete was sufficiently developed for large-scale application.

Three types of concrete were used for the construction of the Passion facade: cyclopean or mass concrete, reinforced concrete, and precast concrete (Grima et al. 2007). The cyclopean or mass concrete was used for the construction of the foundations and as a resistant core in the facade walls lined with Montjuic stone. Moreover, reinforced concrete was applied to specific structural elements such as the foundation slab of the Passion facade, the entrance columns and relieving arches. Finally, the precast concrete was used for the construction of the pinnacles of the towers.

The pinnacles of the Passion facade stand at a height of $121.1 \mathrm{~m}$ and $101.9 \mathrm{~m}$ in the central and in the side towers, respectively. With a total height of $28 \mathrm{~m}$, the pinnacles of the
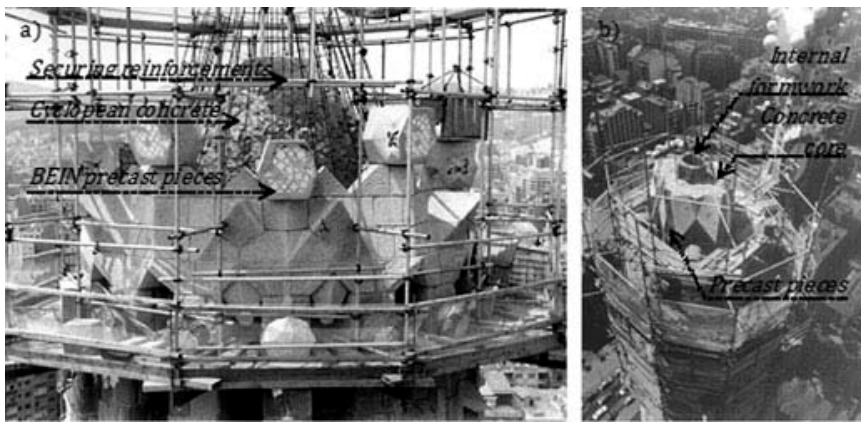

FIG. 12. (a) Construction of the base of the pinnacle, and (b) commencement of construction at the top of the pinnacle. ( $\odot$ (a) Archivo Histórico De La Basílica De La Sagrada Familia. Reproduced by permission of Archivo Histórico De La Basílica De La Sagrada Familia. Permission to reuse must be obtained from the rightsholder.

side towers were composed of two different parts, as in the case of the Nativity facade (a base of $8 \mathrm{~m}$ and a crown of $20 \mathrm{~m})$. As may be observed in Figure 12a, the base was executed in a resistant core of reinforced cyclopean concrete placed in situ and was enclosed by two faces of permanent formwork where the inscriptions Hosanna and Exceleis appear. Unlike the Nativity facade, the exterior face of formwork was made of concrete rather than granite.

Then, the upper or second part of the pinnacle was completed with an exterior permanent formwork of precast pieces covered with trencadis (Figure 12b). These were still manufactured on site, following the same system Gaudí used for the Saint Barnabas tower (Figure 13a). First, the fragments of Murano glass were placed at the bottom of the mold for the trencadis coating. Subsequently, the reinforcement was put in place and finally the mold was filled with concrete. According to an article published in the Temple journal of December 1975, these pieces reached a dimension of $3.5 \mathrm{~m}$ and weighed about 3 tons.

Once dry and turned out of the molds, the pieces were hoisted into position by crane (Figure 13b) and secured by means of

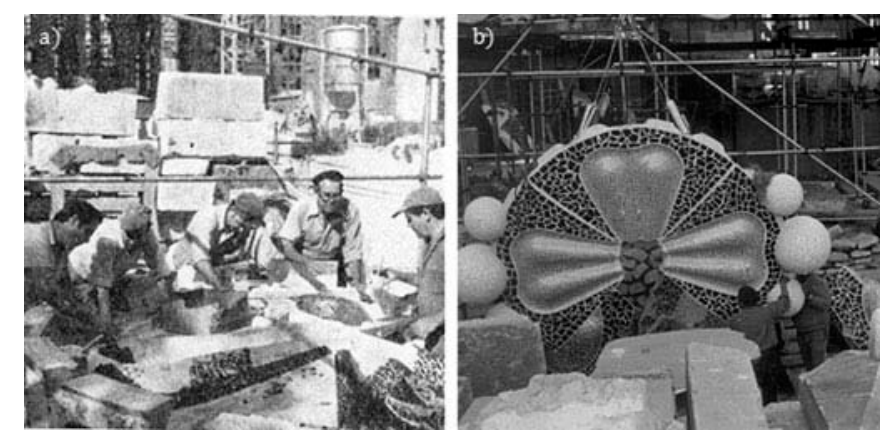

FIG. 13. (a) On-site manufacturing of precast pieces covered with trencadis mosaics and b) hoisting the pieces. ( ) (a) Archivo Histórico De La Basílica De La Sagrada Familia. Reproduced by permission of Archivo Histórico De La Basílica De La Sagrada Familia. Permission to reuse must be obtained from the rightsholder. 

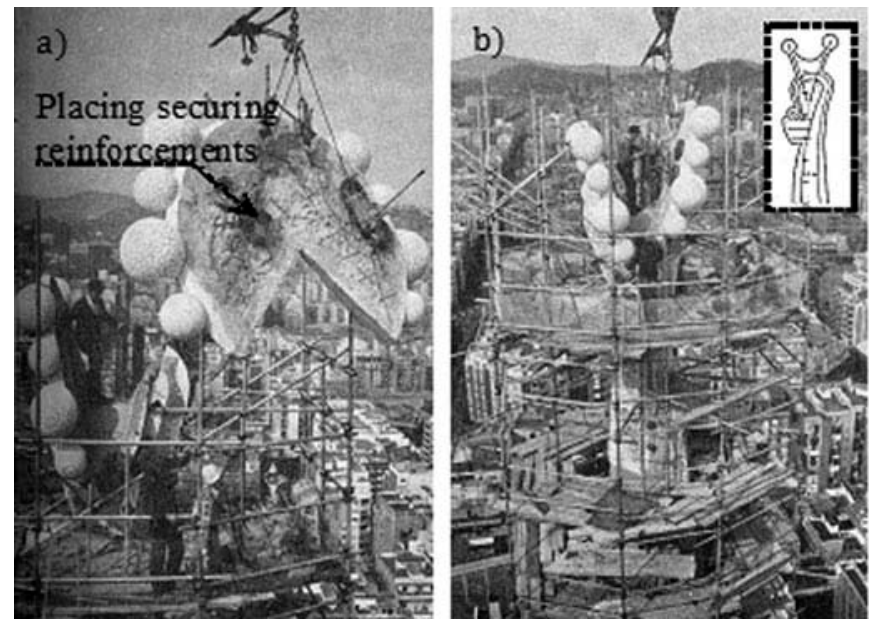

FIG. 14. (a) Positioning of the pinnacle crown and (b) Anchoring securing reinforcements to concrete core. (C) (a) Archivo Histórico De La Basílica De La Sagrada Familia. Reproduced by permission of Archivo Histórico De La Basílica De La Sagrada Familia. Permission to reuse must be obtained from the rightsholder.

reinforcements in the same piece (Figure 14a). As may be observed in in Figure 14b, the securing reinforcements were attached to the resistant concrete core of the pinnacle, following the guidelines in the upper part of the same figure.

\subsection{Third Stage: To The Present Day (1985-2012)}

Following the most recent construction stage at the temple and the enclosure of the central building, a large part of Gaudí's project is now completed. The increase in the pace of construction in comparison with earlier years, is mainly attributed to two reasons: a) the incorporation of new drawing and calculation techniques and $b$ ) increased revenue thanks to the increasing nisitors. The architect Jordi Bonet i Armengol, director of works from 1985 to 2012, in conjunction with the Construction Board of the temple decided to continue to employ precast elements with a trencadis mosaic coating of Murano glass, as Gaudí had done on the Nativity facade.

The new pinnacles are a result of the work of Etsuro Sotoo, a Japanese sculptor (Figure 15a). These are located at different levels $(30$ and $45 \mathrm{~m}$ ) around the entire Basilica and represent various seasonal fruits, grapes and wheat. In addition to that, triangular pieces with a trencadis coating were designed for the interior decoration of the hyperboloids of the building (Figure 15b). An external company now manufactures both types of pieces off-site, given the lack of on-site space around the temple. However, the same factory in Murano from Gaudí's time still supplies the glass used to make those pieces.

This glass continues to be hand crafted, has a thickness of approximately $10 \mathrm{~mm}$ and is delivered on site in the form of glass sheets of approximately $40 \mathrm{~cm}$ in length. The different colored glass undergoes rigorous quality control by means of a thermal shock test and other mechanical tests in order to discard

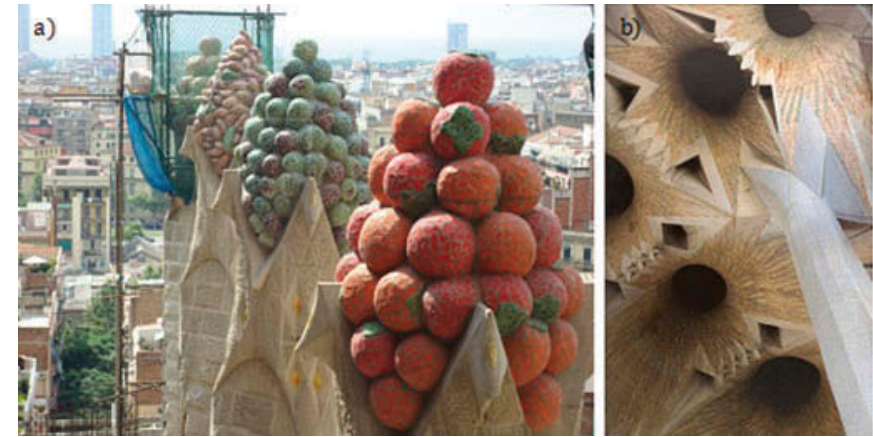

FIG. 15. (a) Pinnacles of the windows in the building (2011), and (b) hyperboloids in the ceiling of the building decorated with Murano glass. (C) (a) J. Bonet. Reproduced by permission J. Bonet. Permission to reuse must be obtained from the rightsholder.

poor-quality products. Subsequently, following quality control, the sheets of glass are cut into small polygonal fragments that make up the unique trencadis coating.

The manufacturing system has changed very little throughout the construction of the temple. On the one hand, polyester molds were used to capture the forms of the pieces for the new pinnacles made by the Japanese sculptor, Sotoo. The small fragments of glass that create the trencadis mosaics were manually positioned with an easily removable silicone gel (Figure 16a and b). Then, internal stainless steel reinforcements were placed in position, before application of the mortar, with a composition of specially selected fine aggregates.

The high workability of the mortar allows it to seep through the trencadis joints to the bottom of the mold. In this way, a completely smooth surface finish is achieved between the two materials. Each piece incorporates securing reinforcements that facilitate its transport and positioning. Finally, a strict curing
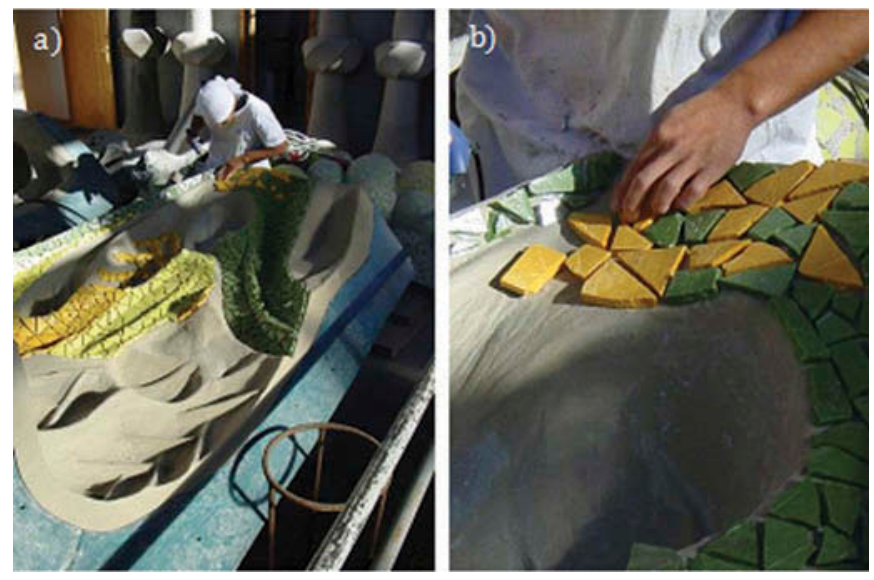

FIG. 16. (a) Positioning of pieces of Murano glass in the molds, and (b) detail of trencadis. () (a) Archivo Histórico De La Basílica De La Sagrada Familia. Reproduced by permission of Archivo Histórico De La Basílica De La Sagrada Familia. Permission to reuse must be obtained from the rightsholder. 

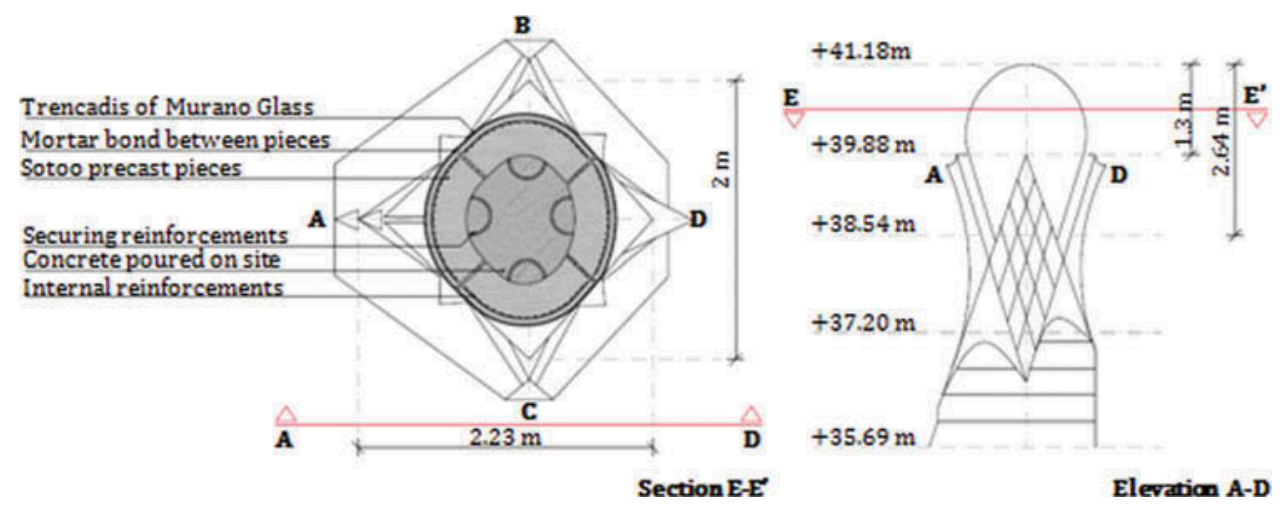

FIG. 17. Plan of the constructive section of the side facade pinnacles.

process is followed to avoid cracking in the hardening and drying process of the mortar pieces. Once completed, the pieces are transported to the site of the temple for assembly.

A plan is presented in Figure 17 of the constructive section of one of the pinnacles that stands over the windows of the lateral facades at a height of $30 \mathrm{~m}$. It has a radius of $2.00 \mathrm{~m}$ and a height of $1.30 \mathrm{~m}$. As may be seen, the section of each pinnacle is composed of several of the previously described pieces that perform a dual function of external coating and as the permanent formwork of the internal concrete core cast in situ. With this system, the securing reinforcement of each piece is embedded in the concrete core. Finally, mortar and fragments of glass fill in the joints between the pieces, assuring the continuity of the facing.

The triangular precast pieces covered with trencadis glass, which today decorate the hyperboloids of the naves were executed with the purpose of accentuating the sunlight that shines into the temple. The manufacturing, curing, and drying of these pieces is practically the same as described above. Figure 18a shows the Preparation of trencadis glass before its assembly in the mold, whereas Figure 18b illustrates the positioning of the reinforcements in the molds prior to casting.
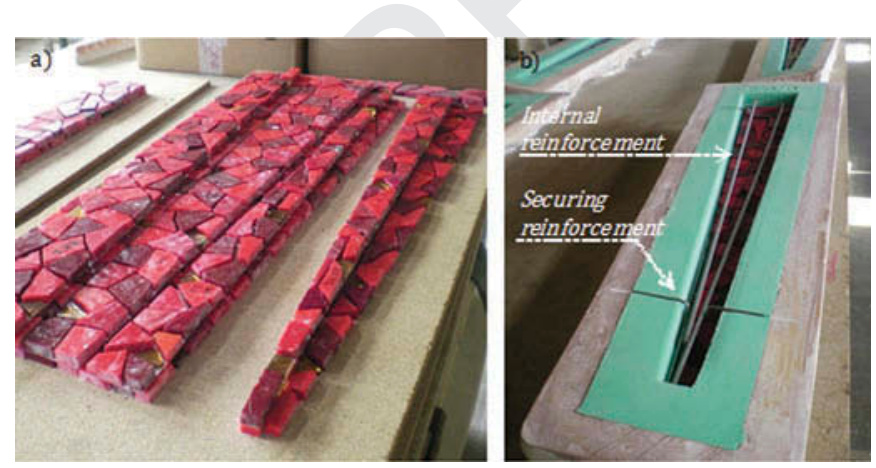

FIG. 18. (a) Preparation of trencadis glass before its assembly in the mold, and (b) Assembly of trencadis and reinforcements in the mold. () (a) Archivo Histórico De La Basílica De La Sagrada Familia. Reproduced by permission of Archivo Histórico De La Basílica De La Sagrada Familia. Permission to reuse must be obtained from the rightsholder.
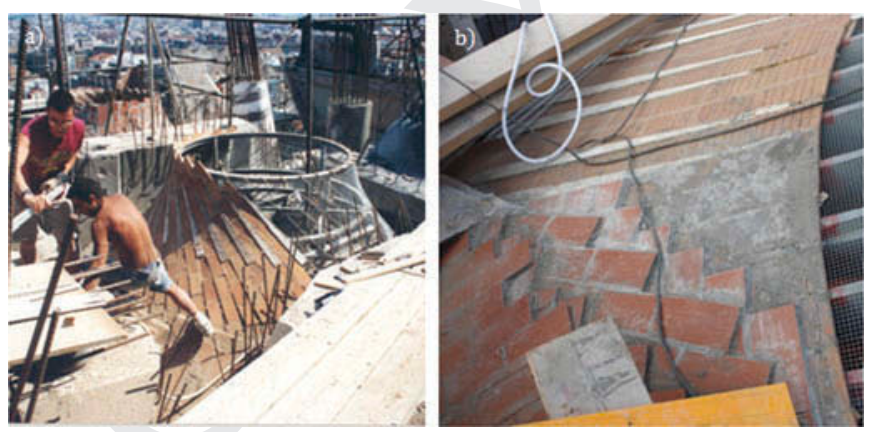

FIG. 19. (a) Construction process of the hyperboloids of the building, and (b) detail of the triangular pieces positioned between the ceramic pieces (ATESF).

The assembly of these pieces was performed at the same time as the construction of the hyperboloids (Gómez et al. 2009). The pieces were alternately placed between layers of ceramic pieces, following the lines of the hyperboloids (Figure 19a). In this process, the securing reinforcements of each piece are embedded between the ceramic layers ensuring the adhesion of the pieces (Figure 19b).

\section{CONCLUSIONS}

The compilation of information presented in this study and its analysis have been done with the objective of understanding the constructive logic that guided the design of the pinnacles that today crown the basilica of the Sagrada Familia. As observed with so many elements designed by Gaudí, it is clear that the architect invested all his genius and knowledge regardless of the structural or the decorative function of the element. The pieces that constitute the pinnacles of his last work are an example of this since they are the result of material and constructive experience gained in the course of his professional life. The Sagrada Familia rises up to the greatest constructed height of all his works. It therefore posed a challenge to the architect, given that it increased all the material and constructive requirements and their on-site application.

\footnotetext{
must be obtained from the rightsholder.
} 
The antecedent of the constructive system for the pinnacles of the temple is found in the work of Parque Güell (1900-1914). It was there that Gaudi consolidated the technique of precast pieces. The use of Portland cement in these pieces also contributed to the success of this new constructive system since it reduced the formwork removal time. This provided the conditions to a serial production that simplified the construction process and made it more flexible.

Gaudí was aware of the deterioration of external trencadis coatings through the experience with a great variety of materials in previous works as well as of the difficulty to repair the pinnacles. The present study has shown that, before choosing the pinnacle coating, Gaudí analyzed several glass tile mosaic works from the island of Sicily (the Palatine Chapel in Palermo, the Duomo di Cefalù and the Duomo di Monreale) using a series of photos brought back from Italy by his friend and disciple, Lluís Bonet.

The construction process of the temple pinnacles has not undergone significant changes since the first model initiated by Gaudí on the Saint Barnabas tower. In fact, the pieces that constitute the new pinnacles of the Basilica still follow the same manufacturing and assembly process, even though their component materials have been updated. Moreover, Murano glass is still used and imported from the same factory as it was in the time of Gaudí.

\section{ACKNOWLEDGEMENTS}

Júlia Gómez expresses her gratitude to the Comissionat per a Universitats del Departament d'Innovació, Universitats i Empresa de la Generalitat de Catalunya [Commission for Universities of the Department of Innovation, Universities and Business of the Catalan Regional Government] and the European Social Fund for the F1 scholarship. Likewise, to the authors thank the Construction Board and the Project Architect of the Basilica of the Sagrada Família for their technical support. The authors extend special thanks to Jordi Faulí, Jordi Coll, Josep Gómez, Ramon Espel and Pau Agut for their valuable contributions to this study.

\section{REFERENCES}

Aguado Martínez M. L., A. Ribas Seix, and C. Hosta Calderer. 2002. La restauración de los pabellones de entrada del Park Güell. Informes de la Construcción 54(481-482):19-28.

Artigas, S. 1955. Pliego de condiciones de construcción de la Losa de Cimentación de la Sagrada Familia. Barcelona, Spain.

Barcelona, Spain: Archivo Histórico De La Basílica De La Sagrada Familia

Bassegoda Nonell, J. 1989. El gran Gaudí. Department Legal B-36.309-89. Barcelona, Spain: Editorial AUSA.
Bassegoda Nonell, J., L. Gueilburt, et al. 2002. La ceràmica en l'obra de Gaudí. Barcelona, Spain: Collegi d'Aparelladors i Arquitectes Tècnics de Barcelona.

Bassegoda Nonell, J. et al. 1984. Antoni Gaudí: 1852-1926. Barcelona, Spain: Centre Cultural de la Caixa de Pensions.

Bassegoda Nonell, J. 1996. L'estudi de Gaudí: Selecció d'articles publicats a la revista temple entre 1971 i 1994 . Department Legal 16057-1996. Barcelona, Spain: Junta Constructora del Temple Expiatori de la Sagrada Família.

Bergós, J., and M. Llimargas. 1999. Gaudí: El Hombre y la obra. Barcelona, Spain: Editorial Lunwerg.

Bonet Armengol, J. 2000. L'Últim Gaudí: El modulat geomètric del Temple de la Sagrada Família. Department Legal 17127-2000. Barcelona, Spain: Edicions Pòrtic.

Bonet, J, T. Cabré, R. Casanova, M. A. Crippa, J. Faulí, D. Giralt-Miracle. 2010. La Sagrada Família de Gaudí: El Temple Expiatori des dels seus orígens fins avui. Department Legal B-40. Barcelona, Spain: Editorial Lunwerg.

Carbonell De Massy, M. 1997. Informe sobre los ensayos realizados en unas muestras de mortero de la fachada del nacimiento de la Sagrada Familia. Barcelona, Spain: Laboratorio Lend Consulting.

Centro Internazionale di Documentazione sul Mosaico (CIDM). 2012. Homepage of CIDM. Available at: http://www.mosaicoravenna.it

Espel, R., R. Grima, A. Aguado, and J. Gómez. 2009. La evolución de la construcción del templo de la Sagrada Familia. Informes de la Construcción 61(516):5-20.

Gómez-Serrano, J. 1996. L'Obrador de Gaudí. Department Legal B.24.329-96. Barcelona, Spain: Edicions UPC.

Gómez-Serrano, J., R. Espel R. Grima, M. C. Burry, and A. Aguado. 2009. Evolution of the formwork used in the temple of the Sagrada Família. International Journal of Architectural Heritage 3(2):93-109.

González Moreno-Navarro, A. 1993. Método y criterios en la restauración del Palau Güell de Barcelona (España). Informes de la Construcción 45(428):19-38.

González Moreno-Navarro, J. L., and A. Casals Balagué. 2002. Gaudí y la razón constructiva: Un legado inagotable. Department Legal M-47.172-2002. Madrid, Spain: Ediciones Akal.

Grima, R. 2004. El hormigón en el Templo de la Sagrada Familia. Escola Tècnica Superior d'Enginyers de Camins, Canals i Ports, Master's Thesis. Barcelona, Spain.

Grima, R., J. Gómez, and A. Aguado. 2007. The use of concrete in Gaudi's Sagrada Familia. International Journal of Architectural Heritage 1(4): 366-379.

Grima, R., A. Aguado, and J. Gómez. 2013. Gaudí and reinforced concrete in construction. International Journal of Architectural Heritage 7(4): $375-402$.

Mañà, F. 2002. Restauración de la plaza del Parque Güell [presentación docente]. Barcelona, Spain:

Martinell, C. 1967. Gaudí: Su vida, su teoría, su obra. Department Legal B 13417-X. Barcelona, Spain: Colegio oficial de arquitectos de Cataluña y Baleares.

Martínez Lapeña, J. A., and E. Torres Tur. 1995. Restauración del Parc Güell de Barcelona. On Diseño 1995(163)142-149.

Matamala Flotats, J. 1999. Antoni Gaudí: Mi itinerario con el arquitecto. Department Legal 36424-1999. Barcelona, Spain: Editorial Claret, S.A.

Paricio, I. 1981. El Park Güell De Barcelona: Una lección de construcción. CAU, Marzo, 1981(70):46-62.

Puig Boada, I. 1929. El Temple de la Sagrada Família. Collecció Sant Jordi. Barcelona, Spain: Editorial Barcino.

Velmans, T., V. Korac, and M. Suput. 1999. Bizancio. El esplendor del arte monumental. Department Legal B-28353-1999. Barcelona, Spain: Lundwerg Editores. 